\title{
Competitiveness and Public Debts in Times of Crisis
}

\author{
Thomas Poufinas $^{1 *}$, George Galanos ${ }^{1}$, Pyrros Papadimitriou ${ }^{2}$ \\ ${ }^{1}$ Department of Economics, Democritus University of Thrace, Xanthi, Greece \\ ${ }^{2}$ Department of Political Science and International Relations, University of Peloponnese, Corinth, Greece \\ Email: ^tpoufinas@gmail.com
}

How to cite this paper: Poufinas, T., Galanos, G. and Papadimitriou, P. (2018) Competitiveness and Public Debts in Times of Crisis. Modern Economy, 9, 1491-1510. https://doi.org/10.4236/me.2018.99094

Received: July 23, 2018

Accepted: August 31, 2018

Published: September 3, 2018

Copyright (c) 2018 by authors and Scientific Research Publishing Inc. This work is licensed under the Creative Commons Attribution International License (CC BY 4.0).

http://creativecommons.org/licenses/by/4.0/

\begin{abstract}
It is observed that countries, possibly more than ever, try to remain or become (more) competitive. This has been felt especially during the recent economic crisis, when countries facing a high debt or deficit attempted to find solutions to overcome it. In most cases the first measures attempted to confront debt or deficit, whatever the problem was. Competitiveness and growth have been discussed but always came second. Sometimes, they were not even considered early enough, although they are of equal or even higher importance. We believe that a country should remain competitive at all times, especially at times of crisis, as it can help it contain its debt (public and private). We even trust that countries that maintain their competitiveness are more capable in weathering adverse economic environments. The purpose of this article is to prove, using an econometric model, the existence of a relationship between the external competitiveness of an economy and its public and private sector deficits, as measured by the relevant debt levels. We indeed find evidence that public and private debt is definitely linked to the country competitiveness as measured by GDP growth, GDP per capita, ease of doing business, tax rate, pensions and unemployment. This can be of use to institutions and policy makers when they want to decide how they will secure that their country is and remains competitive, especially in times of crisis.
\end{abstract}

\section{Keywords}

Competitiveness, Crisis, Euro-Zone Public Debt, Structure of the External Balance of Payments

\section{Introduction}

Competitiveness affects all sectors of economy, products and services produced by the private sector, products and services produced by the public sector, mar- 
ketable goods and services, non-market goods and services, financial services, businesses operating in the real economy-households, and the state. All the above factors and sectors are directly linked to public debt, something that might have been felt in countries especially in Europe during the economic crisis of the last decade, when the twin debt and competitiveness deficits made their presence strongly felt.

Using a combination of the basic definitions that exist in international bibliography, competitiveness refers to the whole economic life of a country in an internationalized environment and describes the country's ability to achieve continuous improvements in the living standards and employment opportunities of its citizens. At the same time, the economic crisis is still the point of interest, especially for the countries of the European South. Today the Eurozone faces a crisis of both public debt and public deficits, particularly for the countries of the South, with significant consequences both to the development process as well as to the competitiveness of these countries.

In this paper we try to analyze the relationship between the deterioration of macroeconomic data and the debt crisis that followed the global financial crisis and has led the institutions and member states of the European Union (i.e., Austria, Italy, Belgium, Latvia, Bulgaria, Lithuania, Croatia, Luxembourg, Cyprus, Malta, Czech Republic, Netherlands, Denmark, Poland, Estonia, Portugal, Finland, Romania, France, Slovakia, Germany, Slovenia, Greece, Spain, Hungary, Sweden, Ireland, United Kingdom) to adopt policies designed to address these imbalances, both in fiscal and monetary terms, in direct correlation with the competitiveness of these countries. Our data sources are the OECD, Eurostat, and AMECO. We use an econometric approach to identify the direct relationship between public or private debt and the factors that affect competitiveness.

It seems that this relationship has been researched in the past; however each author addresses it from a different perspective or with a more focused approach in terms of variables, period of investigation or countries of interest. In our paper 1) we consider a relatively long period of time, incorporating the period before the crisis, during the crisis and after the crisis; 2) we expand our research to all the countries of the European Union (19) for which we could find all relevant data-most of them being also in the Eurozone (13); and 3) we test the explanatory capacity of the biggest set of macroeconomic country-specific variables to the public and private debt. Here lies the contribution of our research to the available empirical knowledge in the area, as we manage to find a relationship between the debt (public and private) and competitiveness (as measured by GDP growth, GDP per capita, ease of doing business, tax rate, pensions and unemployment), with the afore mentioned novelties introduced.

The paper is structured as follows: Section 2 discusses the existing literature, Section 3 describes the problem under investigation, Section 4 presents the data, the variables and the methodology, Section 5 shows the regressions run as well as the relevant tables, Section 6 analyzes the results and their implications and 
Section 7 summarizes the conclusions.

\section{Literature Review}

The impact of competitiveness on economic growth and public debt has been the subject of several scientific papers and studies, especially in the last decade. Afonso and Jalles [1] tried to link growth, productivity, and government debt using a panel of 155 developed and developing countries (period 1970-2008). They used growth equations and growth-accounting techniques, also focusing on a number of econometric issues that can have an important bearing on the results, notably, simultaneity, endogeneity, the relevance of nonlinearities, and threshold effects. The results confirm the negative effect of the government debt ratio. In the case of OECD countries, they also concluded that the longer the maturity of the debt, the higher the economic growth. Moreover, the financial crisis is detrimental to growth. Growth is promoted by fiscal consolidation, and higher debt ratios are beneficial to total factor productivity (TFP) growth. The growth impact of a $10 \%$ increase in the debt ratio is $-0.2 \%(0.1 \%)$ for countries with debt ratios above (below) $90 \%$ (30\%) and an endogenous debt ratio threshold of $59 \%$ can be derived. Their research also showed that the budget balance is positively correlated to the TFP growth, capital stock growth, and private investment.

In a similar research, Panizza and Presbitero [2] used an instrumental variable approach on a sample of OECD countries, in order to examine whether public debt has a causal effect on economic growth. The results are consistent with the existing literature that points to a negative correlation between debt and growth. However, if one corrects for endogeneity, the link between debt and growth no longer exists. The tests show that the results are not affected by weak instrument problems, and are robust to relaxing the exclusion restriction. Their finding that there is no evidence that public debt has a causal effect on economic growth is important in light of the fact that the negative correlation between debt and growth is sometimes used to justify policies that assume that debt has a negative causal effect on economic growth. They conclude that 1 ) there are many papers that show that public debt is negatively correlated with economic growth in advanced economies; 2) there is no paper that makes a convincing case for a causal link going from public debt to economic growth in advanced economies; and 3) such a causal link may not exist, and the case that debt has a causal effect on growth in advanced economies still needs to be made.

At the same time, Greiner [3] has analyzed the basic AK endogenous growth model with elastic labor supply and public debt. He has shown that higher debt ratios lead to a crowding-out of private investment and, thus, to lower long-run growth when the government reduces public spending to fulfill its inter-temporal budget constraint. This holds for non-distortionary and non-productive public spending so that there are no allocative effects of government spending. The reason for that outcome is that higher public debt leads to a lower shadow price 
of private capital and to less labor supply, causing households to reduce their savings and investment, leading to lower long-run growth. This effect does not occur when the government reduces lump-sum transfers as a consequence of a higher debt ratio. In this case, the reduction of lump-sum transfers can be seen as a lump-sum tax for households that does not affect the allocation of resources. Consequently, public debt does not affect the long-run balanced growth rate.

Egert [4], contributes to the empirical literature on the debt threshold beyond which negative effects for economic growth appear. He put a variant of the Reinhart-Rogoff dataset to a formal econometric testing. Using nonlinear threshold models, he found very limited evidence in favor of a negative nonlinear relationship between debt and growth for the period from 1946 to 2009. The estimation results are indeed extremely sensitive to non-linear relationships among the time dimension and country coverage considered, data frequency, and assumptions on the minimum number of observations required in each nonlinear regime. In the few cases when a negative nonlinear effect could be identified, a positive relationship between debt and growth was identified below the estimated debt and a negative relationship was identified above the estimated debt. The negative correlation is found to kick in at a much lower level of public debt (between $20 \%$ and $60 \%$ of GDP). This suggests that high-return public investment opportunities may exist at low levels of public infrastructure and debt. These results, based on bivariate regressions on secular time series of central government debt, are largely confirmed on a shorter dataset including general government debt (1960-2010) when using a multivariate growth framework that accounts for traditional drivers of long-term economic growth and model uncertainty.

A theoretical model of endogenous growth, in which the level of the public debt-to-GDP ratio can negatively impact the effects of productive public expenditures on growth, is the main proposition of Teles and Mussolini [5]. This effect occurs because government indebtedness extracts a portion of the young people's savings to pay interest on the debt. The main conclusions obtained from the theoretical model are verified through the use of an econometric model that provides evidence of the validity of the theoretical model. Their empirical analysis controls for time-invariant, country-specific heterogeneity in the growth rates. Furthermore, they addressed endogeneity issues and allowed for heterogeneity across countries in terms of the model parameters. Their approach has enabled them to verify the existence of effects that have already been predicted in the literature, such as the non-linear effects of productive expenditures on growth given the size of the tax burden or given the indebtedness rate. Such effects are negative for direct capital accumulation because they lead to diminishing marginal net returns of capital or savings extracted from the economy to finance public expenditures. In addition to isolating the above effects, they were able to observe that the impact of productive expenditures on growth depends on the size of the debt-to-GDP ratio, because an increase in the magnitude of 
productive expenditures leads to an increase in the productivity of the economy and, thus, to an equilibrium of interest rates. In addition to incorporating the effect of public debt on the relationship between productive expenditures and economic growth, the model also demonstrates that increases in the size of the debt can lead to higher economic growth; the status quo is a healthy fiscal situation, and indebtedness is associated with an increase in productive expenditures.

Gomez-Puig and Sosvilla-Rivero [6] provide new evidence on the possible existence of bi-directional causal relationships between public debt and economic growth in both central and peripheral countries of the European Economic and Monetary Union. They tested for heterogeneity in the bi-directional Granger-causality across both time and space during the period between 1980 and 2013. The results suggest evidence of a "diabolic loop" between low economic growth and high public debt levels in Spain after 2009. Moreover, in the case of Belgium, Greece, Italy, and the Netherlands, variations in public debt have a negative effect on growth after an endogenously determined breakpoint and above a debt threshold that ranges from $56 \%$ to $103 \%$, depending on the country. In addition, their findings suggest that the EMU countries that were studied not only face different initial conditions, but also have heterogeneous relations both between public debt and economic growth and between economic growth and public debt. Their evidence suggests that an increase in the level of public indebtedness, which might be accompanied by a relaxation of austerity programs, may not boost economic growth, but accelerate its decline. Nevertheless, even though they agree that it is imperative to lower public debt over time, they also think that European policymakers need to be aware of the negative short-run effects of fiscal adjustments on growth prospects.

Tamai [7] examined the relationship between deficit-financed fiscal policy and economic growth in the stochastic economy with disturbances attributable to private and public investment volatility. The analysis showed that a higher tax rate on income eliminates fluctuations in the growth rate and increases (decreases) the mean growth rate when the income tax rate is sufficiently low (high). This result implies that promoting economic growth and eliminating fluctuations in growth are (never) compatible if the income tax rate is sufficiently low (high). In response to increased taxation, households can be induced to vary their portfolios to hedge investment risk in a stochastic economy. That is, deficit-financed fiscal policy affects economic growth and its stability not only through investment in private capital and disposal income of households but also through changes in the portfolios of households. Furthermore, it was demonstrated that public finance reforms, such as tax hikes, do not always improve the treasury budget and therefore do not always reduce the debt-to-GDP ratio.

Égert [4] examined whether public debt has a negative nonlinear effect on growth if public debt exceeds $90 \%$ of GDP, by putting a variant of the Reinhart-Rogoff dataset to formal econometric testing. He used nonlinear threshold models and showed that finding a negative nonlinear relationship between the 
public debt-to-GDP ratio and economic growth is extremely difficult and sensitive to modeling choices and data coverage. This suggests that high-return public investment opportunities may exist at low levels of public infrastructure and debt. The main conclusion is that the results broadly confirm findings of the recent literature. The paper also showed that the negative nonlinear relationship between public debt and economic growth cannot be taken for granted. Indeed, nonlinear effects might be more complex and difficult to model than previously thought.

Gossé and Serranito [8] studied the long-run determinants of current account balances in 21 OECD countries. Specifically, they define long-run targets to determine whether actual current account balances are in line with their equilibrium values. The main conclusion is that the speed of convergence is much faster in deficit countries than in surplus ones. Since 2003, the main northern euro area countries did not show any tendency towards convergence. After the financial crisis, the United Stated and Japan returned towards their long-run targets. In parallel, the actual current account balances of the FANG (Finland, Austria, the Netherlands and Germany) have diverged significantly from their structural levels, whereas in the GIIPS (Greece, Ireland, Italy, Portugal and Spain) the current account balances are much more in line with their long-term targets, with the exception of Greece and Spain.

Moreover, the analysis of Checherita-Westphal and Rother [9] [10] in their 2013 paper "The impact of high government debt on economic growth and its channels: An empirical investigation for the euro area" concludes that public debt has a non-linear impact on per-capita GDP growth across twelve euro area countries for the period since 1970. The paper shows that public debt is associated, on average, with lower long-term growth rates at debt levels above the range of $90 \%-100 \%$ of GDP. The long-term perspective is reinforced by the evidence of a similar impact of public debt on the potential/trend GDP growth rate. From an econometric perspective, the paper deals with the potential endogeneity problem, in particular with the issue of simultaneity or reverse causation, in various ways. They also suggest that the current debt levels of many countries may already have a detrimental impact on their GDP growth, given that the euro area average debt-to-GDP ratio is already above the lower confidence threshold. Private savings, public investment and total factor productivity are the channels through which public debt is found to have a non-linear impact on economic growth. Moreover they suggest that while these relationships are estimated individually, the public debt may influence economic growth through several channels simultaneously.

Kourtellos, Stengos, and Tan [11] investigated the heterogeneous effects of debt on growth, using public debt as a threshold variable, as well as several other plausible variables and employing a structural threshold regression methodology. Their paper shifted the focus of research on the long-run effects of "high levels" of public debt towards its interplay with the deep (fundamental) determinants of growth, as recently proposed by the new growth theories. The findings 
showed that, once a rich set of alternative theories are considered, there is very little evidence for such nonlinearities. Also, they showed that the relationship between public debt and growth is mitigated crucially by the quality of a country's institutions. When a country's institutions are below a particular quality level, more public debt leads to lower growth (all else equal).

At the same time, gathering Greek data for a 40-year period (1970-2010), Spilioti and Vamvoukas [12] examine the link between economic growth and government debt. They have taken into account the different levels of economic growth in the country during that period. They also included indicators related to fiscal policy-which affects economic growth-to country's ability to invest and in the short run finance its expenses, and to the openness and external competitiveness of the economy, as well as variables that are related to its demographic characteristics. The results suggested that key factors such as government debt, per capita gross domestic product and gross national savings represent important determinants of the growth rate of the gross domestic product. The results also suggested that the inclusion of some other control variables in the estimation of growth equation has an important impact on GDP growth. More specifically, other independent variables such as the sum of imports and exports, the trade of goods and services and the growth rate of trade in goods and services, the balance of current transactions with the rest of the world, unemployment, total population and the growth rate of population, are statistically significant and explain a large portion of the variability of the dependent variable. The results support the existence of a statistically significant relationship between government debt and GDP growth.

Ca' Zorzi, Chudik, and Dieppe [13] investigated the importance of evaluating model and parameter uncertainty prior to reaching any firm conclusion, with the aim to contribute to the existing literature. They used three alternative econometric strategies: examining all models, selecting a few, and combining them all. The paper showed that there are thousands, if not millions, of models, which may lead to different conclusions on whether disequilibria exist, as well as on their size. As regards policy conclusions, they explored different routes corresponding to three alternative plausible econometric strategies: examining all models, selecting a few, and combining them all. The main conclusion is that, based on this approach, the chance that current accounts were aligned with fundamentals prior to the financial crisis appears to be minimal.

In conclusion, many scientific studies clearly identify the factors that make up the systems of measuring competitiveness and economic growth, and are more or less related with public debt. However, there seems to be no direct correlation between public debt and competitiveness indicators, as well as the factors that influence competitiveness, especially in countries hit by the European debt crisis in Europe over the past decade, which is also the subject of this paper.

\section{Problem Description}

The problem addressed is the effect of the competitiveness of a country on the 
public and private debt of that country. The country competitiveness is captured by the competitiveness index, imports, gross fixed capital formation, the investments/GDP ratio, consumption, labor cost, exports, the CPI (consumer price index), GDP per capita and productivity, FDI inflows, the GDP, GDP growth, political stability, the corporate income tax rate, the ease of doing business, corruption, the number of labor unions, the pensioners (as a percentage), unemployment (as a percent), the pensions (as a percent of GDP), and the corporate tax rate. The debt is measured by public debt (as a percentage of GDP), private sector debt (consolidated as a percentage of GDP), the net external debt (as a percentage of GDP), total financial sector liabilities (consolidated and as a percentage change from the previous period), and total financial sector liabilities by subsectors (consolidated, as a percentage of GDP and for financial corporations).

We chose this approach as we observed that countries that exhibit certain competitiveness characteristics in terms of their economic activity seem to have lower public debt. We wanted to investigate that also for private debt, as it is anticipated that the competitiveness of a country can have benefits for the private sector as well.

\section{Data, Variables and Methodology}

\subsection{Data}

Our dataset consists of nineteen countries of the European Union (Austria, Belgium, Czech Republic, Denmark, Estonia, France, Germany, Greece, Hungary, Ireland, Italy, Latvia, Netherlands, Poland, Portugal, Slovak Republic, Slovenia, Spain, and the UK). The relevant country figures are for the period 2000-2016 and come from the OECD, Eurostat, the World Bank and AMECO [14]-[23]. We use averages for the period under investigation, as on one hand we wanted to capture the global trend of that period that contained also the crisis and on the other hand we did not have data for the same years for all the variables and all the countries.

\subsection{Descriptive Statistics}

We hereby present the main descriptive statistics of our dataset, i.e. the average, the standard deviation, the minimum, the maximum, as well as the number of observations.

We only kept the countries for which we could find data for all variables (Table 1). To make sure that for all these countries we would have comparable results we took averages for the years under investigation (2000-2016).

\subsection{Variables}

The variables that are used as measures of the competitiveness of an economy-and are the independent variables in our model-are the competitiveness index, imports, gross fixed capital formation, the investments/GDP ratio, consumption, 
Table 1. Descriptive statistics.

\begin{tabular}{|c|c|c|c|c|c|c|c|}
\hline Descriptive Statistics & $\begin{array}{l}\text { Competitiveness } \\
\text { Index }\end{array}$ & Imports & $\begin{array}{l}\text { Gross fixed } \\
\text { capital } \\
\text { formation }\end{array}$ & Investments/GDP & Consumption & Exports & CPI index \\
\hline Average & 98 & 367 & 128 & 23 & 672 & 377 & 94 \\
\hline Standanrd Deviation & 5.85 & 481.53 & 157.82 & 3.36 & 728,30 & 508.68 & 3,05 \\
\hline Min & 86 & 9 & 4 & 17 & 10 & 7 & 86 \\
\hline $\operatorname{Max}$ & 116 & 2082 & 506 & 30 & 2448 & 2167 & 97 \\
\hline No of Observations & 19 & 19 & 19 & 19 & 19 & 19 & 19 \\
\hline Descriptive Statistics & $\begin{array}{l}\text { GDP per capita } \\
\text { and productivity }\end{array}$ & FDI Inflows & GDP & GDP growth & $\begin{array}{l}\text { Political } \\
\text { stabilty }\end{array}$ & $\begin{array}{l}\text { Corporate } \\
\text { income tax } \\
\text { rate }\end{array}$ & $\begin{array}{c}\text { Ease of doing } \\
\text { business }\end{array}$ \\
\hline Average & 41 & 18055 & 587 & 2 & 1 & 27 & 74 \\
\hline Standanrd Deviation & 13.89 & 20385.56 & 754.51 & 1.37 & 0.31 & 6.48 & 5.69 \\
\hline Min & 21 & 576 & 14 & 0 & 0 & 14 & 64 \\
\hline $\operatorname{Max}$ & 61 & 77073 & 2503 & 5 & 1 & 36 & 85 \\
\hline No of Observations & 19 & 19 & 19 & 19 & 19 & 19 & 19 \\
\hline Descriptive Statistics & Corruption & Labor unions & $\%$ Pensioneers & Unemployment & $\begin{array}{c}\text { Pensions as a } \% \\
\text { of GDP }\end{array}$ & Profit tax & Labor cost \\
\hline Average & 24 & 26 & 0 & 9 & 9 & 47 & 24070 \\
\hline Standanrd Deviation & 5.35 & 15.33 & 0.04 & 3.38 & 3.10 & 11.72 & 13725.95 \\
\hline Min & 15 & 8 & 0 & 4 & 4 & 26 & 7479 \\
\hline $\operatorname{Max}$ & 33 & 69 & 0 & 16 & 14 & 70 & 47428 \\
\hline No of Observations & 19 & 18 & 19 & 19 & 18 & 19 & 19 \\
\hline Descriptive Statistics & Public Debt & $\begin{array}{c}\text { Private Debt } \\
\text { percent of GDP }\end{array}$ & $\begin{array}{c}\text { Net External } \\
\text { Debt }\end{array}$ & $\begin{array}{c}\text { Government } \\
\text { Gross Debt }\end{array}$ & $\begin{array}{c}\text { Financial } \\
\text { Sector } \\
\text { Liabilities }\end{array}$ & $\begin{array}{l}\text { Financial } \\
\text { liabilities - } \\
\text { subsector }\end{array}$ & $\begin{array}{c}\text { Financial } \\
\text { Liabilities } \\
\text { Instrument }\end{array}$ \\
\hline Average & 63 & 127 & 12 & 1481967 & 8 & 389 & 389 \\
\hline Standanrd Deviation & 30.29 & 51.85 & 75.42 & 3948508.97 & 3.98 & 366.96 & 366.96 \\
\hline Min & 6 & 60 & -262 & 1017 & 3 & 106 & 106 \\
\hline $\operatorname{Max}$ & 132 & 222 & 93 & 17608049 & 17 & 1545 & 1545 \\
\hline No of Observations & 19 & 19 & 19 & 19 & 19 & 19 & 19 \\
\hline
\end{tabular}

Source: Data from the OECD, AMECO, the World Bank and Eurostat [14]-[23].

labor cost, exports, the CPI (consumer price index), GDP per capita and productivity, FDI inflows, the GDP, GDP growth, political stability, the corporate income tax rate, the ease of doing business, corruption, the number of labor unions, the pensioners (as a percentage), unemployment (as a percent), the pensions (as a percent of GDP), and the corporate tax rate. We use public debt (as a percentage of GDP), private sector debt (consolidated as a percentage of GDP), the net external debt (as a percentage of GDP), total financial sector liabilities (consolidated and as a percentage change from the previous period), and 
total financial sector liabilities by subsectors (consolidated, as a percentage of GDP and for financial corporations) as determinants of public and private sector debt. These are the dependent variables of our model. We use the averages for the years 2000-2016 of the above variables, so as to have an indication of the trend.

We note here that public debt (as a percentage of GDP) is defined as the general government debt-to-GDP ratio. According to the OECD (2018), "this is the amount of a country's total gross government debt as a percentage of its GDP. It is an indicator of an economy's health and a key factor for the sustainability of government finance. 'Debt' is commonly defined as a specific subset of liabilities identified according to the types of financial instruments included or excluded. Debt is thus obtained as the sum of the following liability categories (as applicable): currency and deposits; securities other than shares, except financial derivatives; loans; insurance technical reserves; and other accounts payable. Changes in government debt over time reflect the impact of government deficits. This indicator is measured as a percentage of GDP."

Private sector debt according to Eurostat [20] [21] [22] [23] is "the stock of liabilities held by the sectors Non-Financial corporations and Households and Non-Profit institutions serving households. The instruments that are taken into account to compile private sector debt are Debt securities and Loans. Data are presented in consolidated terms, i.e. do not take into account transactions within the same sector, and expressed in \% of GDP."

The net external (or foreign) debtat any given time, as per the Eurostat definition [20] [21] [22] [23], is "the outstanding amount of the actual current (and not contingent) liabilities that require payment(s) of principal and/or interest by the debtor at some point(s) in the future and that are owed to non-residents by residents of an economy. The external debt is the portion of a country's debt that was borrowed from creditors outside the country, including commercial banks, other governments or international financial institutions (such as the International Monetary Fund (IMF) and the World Bank). The assets/liabilities include debt securities, such as bonds, notes and money market instruments, as well as loans, deposits, currency, trade credits and advances due to non-residents. The loans must usually be paid in the currency in which they were made. In order to earn the needed currency, the borrowing country may sell and export goods to the lender's country. The data are expressed in \% of GDP."

Total financial sector liabilities [20] [21] [22] [23] "measure the evolution of the sum of all liabilities (which includes Currency and deposits, Debt securities, Loans, Equity and investment fund shares/ units, Insurance, pensions and standardized guarantee schemes, Financial derivatives and employee stock options and Other accounts payable) of the financial corporation sector. The data are presented in consolidated terms, i.e. data do not take into account transactions within the same sector. The data are expressed as 1 year \% change of the \% of GDP." 
Total financial sector liabilities by subsectors according to Eurostat [20] [21] [22] [23] measure "the evolution of the sum of all liabilities (which includes Currency and deposits, Debt securities, Loans, Equity and investment fund shares/ units, Insurance, pensions and standardized guarantee schemes, Financial derivatives and employee stock options and Other accounts payable) of the financial corporation sector. Data are presented in consolidated terms (i.e. data do not take into account transactions within the same sector), in \% of GDP and for the sub-sectors: Central bank; Deposit-taking corporations except the central bank; MMF; Non-MMF investment funds; Other financial intermediaries, except insurance corporations and pension funds; Financial auxiliaries; Captive financial institutions and money lenders; Insurance corporations and Pension funds."

\subsection{Methodology}

We attempt to use linear regression in order to link the measures of a country's competitiveness with the determinants of the effectiveness of an adjustment program. The regressions we run use one dependent and one independent variable. The general form of the regression equation is:

$$
\text { Debt }=\beta_{0}+\beta_{1} \cdot \text { Competitiveness }+u
$$

where Debt is any of the above variables that reflect the public or private sector debtor liability and Competitiveness is any of the variables that determine the competitiveness of a country. We use the Stata econometric software to run these linear regressions with Ordinary Least Squares (OLS). We use White's test to detect potential heteroskedasticity and we use Robust Standard Errors to tackle it when present.

\section{Regressions}

We regressed each of the independent variables with each of the dependent variables that are shown in the following Table 2 \& Table 3 and explained in the results section below.

\section{Results and Implications}

The regressions of public debt with each of the independent variables show that it is negatively correlated with the investment/GDP ratio, GDP growth, GDP per capita at all levels, as well as the ease of doing business at the $10 \%$ level. It is positively correlated with the corporate income tax rate and the pensions (as a percentage of GDP) at all significance levels. The remaining variables show no statistical significance. This means that the higher the investments as a portion of GDP, the lower the public debt. The same applies to GDP growth, GDP per capita, and the ease of doing business. This means that competitive economies attract sources of income that allow for low levels of public debt. On the other hand, the positive relation of public debt with the corporate income tax rate and pensions is probably explained by the fact that countries which are perceived as 
Table 2. (a) \& (b) Regressions Summary—Public Debt; (c) \& (d) Regressions Summary—Private Debt.

(a)

\begin{tabular}{|c|c|c|c|c|c|c|c|c|c|c|}
\hline $\begin{array}{l}\text { Variables/ } \\
\text { Regressions }\end{array}$ & (1) & (2) & (3) & (4) & (5) & (6) & (7) & (8) & (9) & (10) \\
\hline \multicolumn{11}{|l|}{$\begin{array}{l}\text { Dependent } \\
\text { Variables }\end{array}$} \\
\hline Public Debt & $\mathrm{X}$ & $\mathrm{X}$ & $\mathrm{X}$ & $\mathrm{X}$ & $\mathrm{X}$ & $\mathrm{X}$ & $\mathrm{X}$ & $\mathrm{X}$ & $\mathrm{X}$ & $\mathrm{X}$ \\
\hline \multicolumn{11}{|l|}{$\begin{array}{l}\text { Independent } \\
\text { Variables }\end{array}$} \\
\hline $\begin{array}{l}\text { Competitiveness } \\
\text { Index }\end{array}$ & $\begin{array}{c}1.129414 \\
(0.92)\end{array}$ & & & & & & & & & \\
\hline Imports & & $\begin{array}{c}-0.0103349 \\
(-0.69)\end{array}$ & & & & & & & & \\
\hline $\begin{array}{l}\text { Gross fixed } \\
\text { capital } \\
\text { formation }\end{array}$ & & & $\begin{array}{c}0.0592634 \\
(1.34)\end{array}$ & & & & & & & \\
\hline $\begin{array}{c}\text { Investments/ } \\
\text { GDP }\end{array}$ & & & & $\begin{array}{c}-5.840119^{\star * *} \\
(-3.51)\end{array}$ & & & & & & \\
\hline Consumption & & & & & $\begin{array}{c}-0.0003959 \\
(-0.04)\end{array}$ & & & & & \\
\hline Labor cost & & & & & & $\begin{array}{c}0.0006696 \\
(1.31)\end{array}$ & & & & \\
\hline Exports & & & & & & & $\begin{array}{c}-0.0101425 \\
(-0.71)\end{array}$ & & & \\
\hline CPI & & & & & & & & $\begin{array}{c}3.086321 \\
(1.35)\end{array}$ & & \\
\hline FDI inflows & & & & & & & & & $\begin{array}{c}0.0003091 \\
(0.88)\end{array}$ & \\
\hline GDP & & & & & & & & & & $\begin{array}{c}0.0121413 \\
\quad(1.31)\end{array}$ \\
\hline Constant & $\begin{array}{c}-48.24271 \\
(-0.40)\end{array}$ & $\begin{array}{c}66.29429^{* * *} \\
(7.40)\end{array}$ & $\begin{array}{c}54.93577^{* * *} \\
(6.21)\end{array}$ & $\begin{array}{c}198.8667^{* * *} \\
(5.07)\end{array}$ & $\begin{array}{c}62.77113^{* * *} \\
(6.37)\end{array}$ & $\begin{array}{c}46.38795^{\star * *} \\
(3.30)\end{array}$ & $\begin{array}{c}66.32763^{* * *} \\
(7.49)\end{array}$ & $\begin{array}{c}-227.0245 \\
(-1.06)\end{array}$ & $\begin{array}{c}56.92387 \\
(6.02)\end{array}$ & $\begin{array}{c}55.37289^{* * *} \\
(6.35)\end{array}$ \\
\hline Observations & 19 & 19 & 19 & 19 & 19 & 19 & 19 & 19 & 19 & 19 \\
\hline $\begin{array}{l}\text { Adjusted } \\
\text { R-squared }\end{array}$ & -0.0084 & -0.0302 & 0.0422 & 0.3857 & -0.0587 & 0.0387 & -0.0281 & 0.0435 & -0.0130 & 0.0380 \\
\hline
\end{tabular}

Notes: $t$-values in parenthesis; ${ }^{* *}$ statistically significant at the $1 \%$ level; ${ }^{* *}$ statistically significant at the $5 \%$ level; ${ }^{*}$ statistically significant at the $10 \%$ level.

(b)

\begin{tabular}{|c|c|c|c|c|c|c|c|c|c|c|c|}
\hline $\begin{array}{l}\text { Variables/ } \\
\text { Regressions }\end{array}$ & (11) & (12) & (13) & (14) & (15) & (16) & (17) & (18) & (19) & (20) & (21) \\
\hline $\begin{array}{l}\text { Dependent } \\
\text { Variables }\end{array}$ & & & & & & & & & & & \\
\hline Public Debt & $\mathrm{X}$ & $\mathrm{X}$ & $\mathrm{X}$ & $\mathrm{X}$ & $\mathrm{X}$ & $\mathrm{X}$ & $\mathrm{X}$ & $\mathrm{X}$ & $\mathrm{X}$ & $\mathrm{X}$ & $\mathrm{X}$ \\
\hline $\begin{array}{c}\text { Independent } \\
\text { Variables }\end{array}$ & & & & & & & & & & & \\
\hline $\begin{array}{l}\text { GDP per capita } \\
\text { \& productivity }\end{array}$ & $\begin{array}{c}0.7399537 \\
(1.49)\end{array}$ & & & & & & & & & & \\
\hline GDP growth & & $\begin{array}{c}-15.9495^{* * *} \\
(-4.32)\end{array}$ & & & & & & & & & \\
\hline
\end{tabular}




\section{Continued}

\begin{tabular}{|c|c|c|c|c|c|c|c|c|c|c|c|}
\hline $\begin{array}{l}\text { Political } \\
\text { stability }\end{array}$ & & & $\begin{array}{c}-25.50482 \\
(-1.12)\end{array}$ & & & & & & & & \\
\hline $\begin{array}{c}\text { Corporate } \\
\text { income tax rate }\end{array}$ & & & & $\begin{array}{c}2.862345^{* * *} \\
(3.19)\end{array}$ & & & & & & & \\
\hline $\begin{array}{l}\text { Ease of doing } \\
\text { business }\end{array}$ & & & & & $\begin{array}{c}-2.035551^{*} \\
(-1.71)\end{array}$ & & & & & & \\
\hline Corruption & & & & & & $\begin{array}{c}-1.14754 \\
(-0.85)\end{array}$ & & & & & \\
\hline Labor unions & & & & & & & $\begin{array}{c}0.3499813 \\
(0.73)\end{array}$ & & & & \\
\hline Pensioners & & & & & & & & $\begin{array}{c}-148.5361 \\
(-0.75)\end{array}$ & & & \\
\hline $\begin{array}{c}\text { Pensions as \% } \\
\text { of GDP }\end{array}$ & & & & & & & & & $\begin{array}{c}5.670439^{* * *} \\
(2.93)\end{array}$ & & \\
\hline Profit tax & & & & & & & & & & $\begin{array}{c}1.038297^{*} \\
(1.81)\end{array}$ & \\
\hline Unemployment & & & & & & & & & & & $\begin{array}{c}0.3181745 \\
(0.15)\end{array}$ \\
\hline Constant & $\begin{array}{c}31.86698 \\
(1.47)\end{array}$ & $\begin{array}{c}95.89791^{* * *} \\
(10.45)\end{array}$ & $\begin{array}{c}81.77793^{* * *} \\
(4.41)\end{array}$ & $\begin{array}{c}-13.36755 \\
(-0.55)\end{array}$ & $\begin{array}{c}213.592^{\star *} \\
(2.41)\end{array}$ & $\begin{array}{c}89.49843^{* * *} \\
(2.76)\end{array}$ & $\begin{array}{c}55.36742^{* * *} \\
(3.84)\end{array}$ & $\begin{array}{c}100.3165^{*} \\
(1.97)\end{array}$ & $\begin{array}{c}13.71019 \\
(0.75)\end{array}$ & $\begin{array}{c}14.11287 \\
(0.615)\end{array}$ & $\begin{array}{c}59.62675^{* * *} \\
(2.85)\end{array}$ \\
\hline Observations & 19 & 19 & 19 & 19 & 19 & 19 & 18 & 19 & 18 & 19 & 19 \\
\hline $\begin{array}{l}\text { Adjusted } \\
\text { R-squared }\end{array}$ & 0.0631 & 0.4952 & 0.0141 & 0.3382 & 0.0962 & -0.0154 & -0.0279 & -0.0249 & 0.3092 & 0.1121 & -0.0575 \\
\hline
\end{tabular}

Notes: $t$-values in parenthesis; ${ }^{* *}$ statistically significant at the $1 \%$ level; ${ }^{* *}$ statistically significant at the $5 \%$ level; ${ }^{*}$ statistically significant at the $10 \%$ level.

(c)

\begin{tabular}{|c|c|c|c|c|c|c|c|c|c|c|}
\hline $\begin{array}{l}\text { Variables/ } \\
\text { Regressions }\end{array}$ & (1) & (2) & (3) & (4) & (5) & (6) & (7) & (8) & (9) & (10) \\
\hline $\begin{array}{c}\text { Dependent } \\
\text { Variables }\end{array}$ & & & & & & & & & & \\
\hline Private Debt & $\mathrm{X}$ & $\mathrm{X}$ & $\mathrm{X}$ & $\mathrm{X}$ & $\mathrm{X}$ & $\mathrm{X}$ & $\mathrm{X}$ & $\mathrm{X}$ & $\mathrm{X}$ & X \\
\hline $\begin{array}{c}\text { Independent } \\
\text { Variables }\end{array}$ & & & & & & & & & & \\
\hline $\begin{array}{l}\text { Competitiveness } \\
\text { Index }\end{array}$ & $\begin{array}{c}4.414909^{* *} \\
(2.37)\end{array}$ & & & & & & & & & \\
\hline Imports & & $\begin{array}{c}-0.018844 \\
(-0.73)\end{array}$ & & & & & & & & \\
\hline $\begin{array}{l}\text { Gross fixed } \\
\text { capital } \\
\text { formation }\end{array}$ & & & $\begin{array}{c}0.0390582 \\
(0.49)\end{array}$ & & & & & & & \\
\hline $\begin{array}{c}\text { Investments/ } \\
\text { GDP }\end{array}$ & & & & $\begin{array}{c}-6.12841^{*} \\
(-1.78)\end{array}$ & & & & & & \\
\hline Consumption & & & & & $\begin{array}{c}-0.0087811 \\
(-0.51)\end{array}$ & & & & & \\
\hline Labor cost & & & & & & $\begin{array}{c}0.0029544^{* * *} \\
(5.18)\end{array}$ & & & & \\
\hline Exports & & & & & & & $\begin{array}{c}-0.0157317 \\
(-0.64)\end{array}$ & & & \\
\hline CPI & & & & & & & & $\begin{array}{c}9.402788^{\star * *} \\
(2.74)\end{array}$ & & \\
\hline
\end{tabular}




\section{Continued}

\begin{tabular}{|c|c|c|c|c|c|c|c|c|c|c|}
\hline FDI inflows & & & & & & & & & $\begin{array}{c}0.0011414^{* *} \\
(2.07)\end{array}$ & \\
\hline GDP & & & & & & & & & & $\begin{array}{c}0.0079359 \\
(0.48)\end{array}$ \\
\hline Constant & $\begin{array}{c}-305.4736 \\
(-1.67)\end{array}$ & $\begin{array}{c}134.351 \\
(8.78)\end{array}$ & $\begin{array}{c}122.4532 \\
(7.75)\end{array}$ & $\begin{array}{c}270.5348^{* * *} \\
(3.34)\end{array}$ & $\begin{array}{c}133.3455^{* * *} \\
(7.97)\end{array}$ & $\begin{array}{c}56.32925^{\star * *} \\
(3.58)\end{array}$ & $\begin{array}{c}133.371^{* * *} \\
(8.78)\end{array}$ & $\begin{array}{c}-754.6387^{* *} \\
(-2.34)\end{array}$ & $\begin{array}{c}106.8336^{* * *} \\
(7.22)\end{array}$ & $\begin{array}{c}122.78^{* * *} \\
(7.89)\end{array}$ \\
\hline Observations & 19 & 19 & 19 & 19 & 19 & 19 & 19 & 19 & 19 & 19 \\
\hline $\begin{array}{l}\text { Adjusted } \\
\text { R-squared }\end{array}$ & 0.2042 & -0.0264 & -0.0439 & 0.1082 & -0.0427 & 0.5889 & -0.0336 & 0.2654 & 0.1544 & -0.0447 \\
\hline
\end{tabular}

Notes: $\mathrm{t}$-values in parenthesis; ${ }^{\star * *}$ statistically significant at the $1 \%$ level; ${ }^{\star *}$ statistically significant at the $5 \%$ level; ${ }^{\star}$ statistically significant at the $10 \%$ level.

(d)

\begin{tabular}{|c|c|c|c|c|c|c|c|c|c|c|c|}
\hline $\begin{array}{l}\text { Variables/ } \\
\text { Regressions }\end{array}$ & (11) & (12) & (13) & (14) & (15) & (16) & (17) & (18) & (19) & (20) & (21) \\
\hline \multicolumn{12}{|l|}{$\begin{array}{l}\text { Dependent } \\
\text { Variables }\end{array}$} \\
\hline \multicolumn{12}{|l|}{ Private Debt } \\
\hline \multicolumn{12}{|l|}{$\begin{array}{c}\text { Independent } \\
\text { Variables }\end{array}$} \\
\hline \multicolumn{12}{|c|}{ GDP per capita2.490718 } \\
\hline GDP growth & & $\begin{array}{c}-8.759206 \\
(-0.98)\end{array}$ & & & & & & & & & \\
\hline $\begin{array}{l}\text { Political } \\
\text { stability }\end{array}$ & & & $\begin{array}{c}38.97029 \\
(0.99)\end{array}$ & & & & & & & & \\
\hline $\begin{array}{l}\text { Corporate } \\
\text { income tax rate }\end{array}$ & & & & $\begin{array}{c}1.165138 \\
(0.61)\end{array}$ & & & & & & & \\
\hline $\begin{array}{l}\text { Ease of doing } \\
\text { business }\end{array}$ & & & & & $\begin{array}{c}5.512327^{* * *} \\
(3.13)\end{array}$ & & & & & & \\
\hline Corruption & & & & & & $\begin{array}{c}6.875932^{* * *} \\
(4.14)\end{array}$ & & & & & \\
\hline Labor unions & & & & & & & $\begin{array}{c}1.345414^{*} \\
(1.71)\end{array}$ & & & & \\
\hline Pensioners & & & & & & & & $\begin{array}{c}-868.77^{* * *} \\
(-3.19)\end{array}$ & & & \\
\hline $\begin{array}{c}\text { Pensions as \% } \\
\text { of GDP }\end{array}$ & & & & & & & & & $\begin{array}{c}-8.046028^{\star *} \\
(-2.17)\end{array}$ & & \\
\hline Profit tax & & & & & & & & & & $\begin{array}{c}-1.803657^{\star} \\
(-1.84)\end{array}$ & \\
\hline Unemployment & & & & & & & & & & & $\begin{array}{c}-6.59467^{*} \\
(-1.96)\end{array}$ \\
\hline Constant & $\begin{array}{c}24.31297 \\
(0.83)\end{array}$ & $\begin{array}{c}145.7806^{* * * 9} \\
(6.59)\end{array}$ & $\begin{array}{c}97.99344^{\star * \star} \\
(3.07)\end{array}$ & $\begin{array}{c}* 96.55731^{*} \\
(1.85)\end{array}$ & $\begin{array}{c}-281.706^{\star *} \\
(-2.15)\end{array}$ & $\begin{array}{c}-34.30017 \\
(-0.86)\end{array}$ & $\begin{array}{c}94.22128^{* * *} \\
(3.96)\end{array}$ & $\begin{array}{c}348.5984^{* * *} 2 \\
(4.98)\end{array}$ & $\begin{array}{c}201.8612^{\star * \star} \\
(5.74)\end{array}$ & $\begin{array}{c}211.5051^{\star * *} \\
(4.50)\end{array}$ & $\begin{array}{c}187.0969^{* * *} \\
(5.78)\end{array}$ \\
\hline Observations & 19 & 19 & 19 & 19 & 19 & 19 & 18 & 19 & 18 & 19 & 19 \\
\hline $\begin{array}{l}\text { Adjusted } \\
\text { R-squared }\end{array}$ & 0.4127 & -0.0018 & -0.0008 & -0.0364 & 0.3290 & 0.4734 & 0.1021 & 0.3375 & 0.1784 & 0.1171 & 0.1365 \\
\hline
\end{tabular}

Notes: $t$-values in parenthesis; ${ }^{* *}$ statistically significant at the $1 \%$ level; ${ }^{* *}$ statistically significant at the $5 \%$ level; ${ }^{*}$ statistically significant at the $10 \%$ level. 
Table 3. Regressions Summary-Public Debt, Private Debt.

\begin{tabular}{ccc}
\hline Variables/Regressions & $(\mathbf{2 2})$ & $(23)$ \\
\hline Dependent Variables & & \\
Public Debt & $\mathrm{X}$ & $\mathrm{X}$ \\
Private Debt & & \\
Independent Variables & & $-25.89107^{* *}$ \\
GDP growth & $-18.60453^{* *}$ & $(-2.37)$ \\
& $(-2.78)$ & $2.605455^{* * *}$ \\
GDP per capita \& productivity & $1.145167^{*}$ & $(2.89)$ \\
Pensions as \% of GDP & $(2.08)$ & -9.671682 \\
& $3.828558^{*}$ & $(-2.74)$ \\
Unemployment & $(1.77)$ & 2.18928 \\
& $3.945936^{*}$ & $(0.72)$ \\
Corporate income tax rate & $(2.12)$ & -3.533783 \\
& -2.60177 & $(-1.30)$ \\
Constant & $(-1.56)$ & $(3.08)$ \\
Observations & 53.7111 & 18 \\
Adjusted R-squared & $(1.16)$ & 0.6215 \\
\hline
\end{tabular}

Notes: t-values in parenthesis; ${ }^{* * *}$ statistically significant at the $1 \%$ level; ${ }^{* *}$ statistically significant at the $5 \%$ level; * ${ }^{*}$ tatistically significant at the $10 \%$ level. Source: Results of regressions run by the authors using data from the OECD, AMECO, the World Bank and Eurostat [14]-[23].

non-competitive due to their high corporate tax rate and pensions cannot attract other sources of funds. Consequently their public debt is higher. Moreover it could be that part of the public debt is due to the fact that pensions account for a larger portion of GDP.

Private debt is positively correlated with the labor cost, the CPI, the GDP per capita, the ease of doing business, the corruption index at all levels, the competitiveness index, and FDI inflows at the 5\% significance level, and with the number of labor unions at the $10 \%$ level. It is negatively correlated with the pensioners at all levels, the pensions as a percentage of GDP at the 5\% level, and the investments/GDP ratio, unemployment, and the corporate tax rate at the $10 \%$ level. The rest of the variables exhibit no statistical significance. These findings mostly show that the higher the competitiveness as measured by the relevant indexes (ease of doing business, corruption), the higher the private sector debt. This can be explained by the fact that lenders trust the corporations of positively perceived countries. In addition, the higher CPI and GDP per capita could indicate some degree of prosperity that allows higher private sector debt. Moreover, countries that attract higher FDI inflows, also justify higher private sector debt. Labor costs and the number of labor unions could account for increased borrowing to cover increased labor-related expenses. On the other hand, the high number of pensioners, the high percentage of pensions compared to GDP, high unemployment and the high corporate tax rate could be viewed as creating unfavorable conditions for lending corporations, meaning that private sector debt 
is lower in such countries. Moreover, if investments are high as a percentage of GDP, then private sector lending may not be as necessary, and hence it is negatively correlated with such investments.

The net external debt is positively correlated with the corporate income tax rate, the pensioners, and the pensions (as a \% of GDP) at the $10 \%$ significance level. It is negatively correlated with GDP growth at the $5 \%$ level, and with labor cost, political stability and the ease of doing business at the $10 \%$ significance level. The findings are in line with those related to the public debt, and the interpretation is thus similar.

Financial sector liabilities are positively correlated with GDP growth at all levels and with the investments/GDP ratio at the 5\% significance level. They are negatively correlated with the CPI, the GDP per capita and the corporate tax rate at all levels, with the labor cost and the pensions at the 5\% level, and with gross fixed capital formation and the GDP at the 10\% significance level. There is no statistically significant correlation with the other independent variables. The outcomes of the financial sector liabilities regressions indicate that the higher GDP growth and the investments/GDP ratio, the higher the percentage increase of financial sector liabilities, as the financial corporation sector can, apparently, access increased financing in countries that exhibit such conditions. On the other hand, the high CPI probably increases financing costs and thus leads to reduced rate of change of the financial sector liabilities. The high GDP per capita and high GDP potentially reduce the financing needs of financial corporations, as they most likely have other sources of income. The low corporate tax rate probably increases profitability and thus increases investments in assets issued by financial corporations, and thus their liabilities. The low labor cost and the low pensions as a percentage of GDP could mean increased profitability and thus again higher investments in assets issued by the financial corporations and therefore higher financial corporation liabilities. High gross fixed capital formation possibly implies reduced interest in the assets issued by financial corporations and thus leads to a drop in the rate of change of financial sector liabilities.

In addition, we ran a regression of financial sector liabilities against public debt to determine whether they are negatively correlated at all significance levels. This can be probably interpreted by the fact that high public debt implies reduced interest for the assets issued by financial corporations and thus a drop in the financial sector liabilities change.

Financial sector liabilities by subsector (as a \% of GDP) are positively correlated with the labor cost, the GDP per capita, and the ease of doing business at all levels, and with the competitiveness index and the CPI at the 5\% level. They are negatively correlated with the pensioners and the pensions as a percentage of GDP at all levels, the corporate tax at the 5\% level and unemployment at the $10 \%$ level. The other variables show no explanatory significance. This means that the higher the competitiveness of a country, the more easily the financial sector can obtain financing. The same holds when the ease of doing business is perceived as high. Higher GDP per capita potentially means increased interest for the assets 
issued by financial corporations and thus increases their liabilities. The high labor cost could also mean that financial corporations are in greater need of covering this cost. As pensioners, pensions, and unemployment increase it is possible that there are limited funds to be directed to the financial corporations, thus decreasing their liabilities. The same is possible in regard to the impact of high corporate tax rates, which reduce profitability and thus the demand for the assets issued by the financial sector.

To make sure that our findings are valid when we combine all variables, we regressed public debt with GDP growth, GDP per capita and productivity, pensions as a percent of GDP, unemployment and corporate income tax rate to realize that these variables remain significant either for private or for public debt. More specifically, public debt is negatively correlated with GDP growth at the $5 \%$ level, positively correlated with the GDP per capita, the pensions as a $\%$ of GDP and the unemployment at the $10 \%$ level. The private debt is negatively correlated with the GDP growth at the $10 \%$ level and the pensions as a \% of GDP at the $5 \%$ level, whereas it is positively correlated with the GDP per capita at all levels. The net external debt is negatively correlated with the GDP growth at the $10 \%$ level and with the GDP per capita at all levels. Financial sector liabilities are negatively correlated with the GDP per capita at the $10 \%$ level. Financial sector liabilities by subsector are positively correlated with the GDP per capita at all levels and negatively correlated with the income tax rate at the $10 \%$ level. The remaining variables in all cases show no statistical significance. The interpretation remains similar to the one presented in the aforementioned argumentation of the individual regressions. The results are presented in Table 3.

The relationships identified among the measures of the debt of a country and the determinants of its competitiveness indicate that a country (for example Greece) that wishes to contain its public debt (as measured by the general government debt and the net external debt) needs to attract increased investment as a portion of its GDP, secure GDP growth, and create conditions to increase its GDP per capita. In addition it needs to foster a friendly corporate environment with high perceived ease of doing business, affordable corporate income tax rates, and reasonable pensions (as a percent of GDP). All this is maybe well-known empirically, but has also emerged as a finding of our study. Private debt (as measured by financial sector liabilities as a percentage of GDP) is in the same direction with GDP per capita, the ease of doing business, labor cost, the competitiveness index, and the CPI. It moves to the opposite direction from pensions and pensioners, the unemployment and the profit tax. If private debt is viewed as a means of financing, then to attract it countries need to pretty much do what is needed in order to reduce public debt, due to the negative sign of the coefficient of the regression. Consequently, a consistent policy that increases the competitiveness of a country can work towards consolidating GDP growth, GDP per capita, and the perceived ease of doing business, and maintaining pensions, unemployment, and taxes at acceptable levels. 


\section{Conclusions}

The competitiveness of a country is vital both for the public and private debt. It is therefore of great importance to identify the characteristics of economic activity that countries with low public debt exhibit and realize the implications to private debt. In this paper we were able to show that the public and private debt is definitely linked to the country competitiveness as measured by GDP growth, GDP per capita, ease of doing business, tax rate, pensions and unemployment, as evidenced by the regression analysis performed, comparing the relevant figures of our countries of interest. As we did not use panel data, but rather OLS on the averages per country, we leave for future research the investigation of our findings when we use the entire time series, this being a limitation of our research. Ideally, we would like to gain access to the data of more countries, so as to have an even bigger set of countries to apply our findings.

Consequently, a country that wishes to reduce its public debt and attract funds for the private sector lending (as a source of financing) needs to pay attention to these figures and secure that they move in the appropriate direction.

As evidenced by the afore mentioned findings, this can be achieved by proceeding with the necessary reforms that will facilitate the entrepreneurship in the country, rationalize pensions, will create employment opportunities and contain taxes at affordable levels. All these require strong decision making and consistent implementation. The relevant actions are not necessarily conflicting as containing pensions could release resources that can be used to increase employment and stabilize taxes. At the same time fostering entrepreneurship, will also contributes to the same direction. Last but not least, they need to create the conditions that will increase GDP and GDP per capita growth. The previous actions also contribute to this direction as well. As a result, policymakers can concentrate at least on these five directions/metrics to secure that their country will remain or become competitive.

\section{Conflicts of Interest}

The authors declare no conflicts of interest regarding the publication of this paper.

\section{References}

[1] Afonso, A. and Jalles, J.T. (2013) Growth and Productivity: The Role of Government Debt. International Review of Economics and Finance, 25, 384-407. https://doi.org/10.1016/j.iref.2012.07.004

[2] Panizza, U. and Presbitero, A.F. (2014) Public Debt and Economic Growth: Is There a Causal Effect? Journal of Macroeconomics, 41, 21-41. https://doi.org/10.1016/j.jmacro.2014.03.009

[3] Greiner, A. (2012) Public Debt in a Basic Endogenous Growth Model. Economic Modelling, 29, 1344-1348. https://doi.org/10.1016/j.econmod.2012.03.005

[4] Égert, B. (2015) Public Debt, Economic Growth and Nonlinear Effects: Myth or Reality? Journal of Macroeconomics, 43, 226-238. 
https://doi.org/10.1016/j.jmacro.2014.11.006

[5] Teles, V.K. and Mussolini, C.C. (2014) Public Debt and the Limits of Fiscal Policy to Increase Economic Growth, European Economic Review, 66, 1-15.

https://doi.org/10.1016/j.euroecorev.2013.11.003

[6] Gómez-Puig, M. and Sosvilla-Rivero, S. (2015) The Causal Relationship between Debt and Growth in EMU Countries. Journal of Policy Modeling, 37, 974-989. https://doi.org/10.1016/j.jpolmod.2015.09.004

[7] Tamai, T. (2014) Public Capital, Deficit Financing, and Economic Growth, in a Stochastic Economy. Journal of Macroeconomics, 42, 14-26. https://doi.org/10.1016/j.jmacro.2014.06.006

[8] Gossé, J.-B. and Serranito, F. (2014) Long-Run Determinants of Current Accounts in OECD Countries: Lessons for Intra-European Imbalances. Economic Modelling, 38, 451-462. https://doi.org/10.1016/j.econmod.2014.01.008

[9] Checherita-Westphal, C. and Rother, P. (2012) The Impact of High Government Debt on Economic Growth and Its Channels: An Empirical Investigation for the Euro Area, European Economic Review, 56, 1392-1405. https://doi.org/10.1016/j.euroecorev.2012.06.007

[10] Baum, A., Checherita-Westphal, C. and Rother, P. (2013) Debt and GROWTH: New Evidence for the Euro Area. Journal of International Money and Finance, 32, 809-821. https://doi.org/10.1016/j.jimonfin.2012.07.004

[11] Kourtellos, A., Stengos, T. and Tan, C.M. (2013) The Effect of Public Debt on Growth in Multiple Regimes. Journal of Macroeconomics, 38, 35-43. https://doi.org/10.1016/j.jmacro.2013.08.023

[12] Spilioti, S. and Vamvoukas, G. (2015) The Impact of Government Debt on Economic Growth: An Empirical Investigation of the Greek Market. The Journal of Economic Asymmetries, 12, 34-40. https://doi.org/10.1016/j.jeca.2014.10.001

[13] Ca' Zorzi, M., Chudik, A. and Dieppe, A. (2012) Thousands of Models, One Story: Current Account Imbalances in the Global Economy. Journal of International Money and Finance, 31, 1319-1338. https://doi.org/10.1016/j.jimonfin.2012.02.003

[14] OECD (2017). http://stats.oecd.org/

[15] OECD (2017). http://stats.oecd.org/Index.aspx?DatasetCode=STLABOUR\#

[16] UNCTAD (2017). http://unctad.org/en/Pages/statistics.aspx\#

[17] Worldbank (2017).

http://databank.worldbank.org/data/reports.aspx?source=2\&country=GRC\#

[18] AMECO (2017).

http://ec.europa.eu/economy_finance/ameco/user/serie/SelectSerie.cfm

[19] Eurostat (2017) Database. http://ec.europa.eu/eurostat/data/database?p_p_id=NavTreeportletprod_WAR_Nav Treeportletprod_INSTANCE_nPqeVbPXRmWQ\&p_p_lifecycle=0\&p_p_state=normal\&p_p_ $\underline{\text { mode }=\text { view } \& p \_p \_c o l \_i d=c o l u m n-2 \& p \_p \_c o l \_c o u n t=1}$

[20] Eurostat (2018) Net External Debt-Annual Data, \% of GDP. http://ec.europa.eu/eurostat/tgm/table.do?tab=table\&init=1\&plugin=1\&language=e $\underline{\text { n\&pcode }=\text { tipsii20 }}$

[21] Eurostat (2018) Private Sector Debt, Consolidated \% of GDP. http://ec.europa.eu/eurostat/tgm/table.do?tab=table\&init=1\&plugin=1\&language $=\mathrm{e}$ $\underline{\text { n\&pcode }=\text { tipspd } 20}$ 
[22] Eurostat (2018) Total Financial Sector Liabilities, Consolidated. http://ec.europa.eu/eurostat/tgm/table.do?tab=table\&init=1\&plugin=1\&language $=\mathrm{e}$ n\&pcode $=$ tipsfs 30

[23] Eurostat (2018) Total Financial Sector Liabilities, by Sub-Sectors, Consolidated \% of GDP.

http://ec.europa.eu/eurostat/tgm/table.do?tab=table\&init=1\&plugin=1\&language $=\mathrm{e}$ $\underline{\text { n\&pcode }=\text { tipsfs } 31}$ 